Abbe whereby young men of ability, while holding academic appointments, were engaged by Messrs. Zeiss, to the advantage of the collaborator and of the firm. They were afforded the opportunity, so often lacking elsewhere, of communicating direct to the firm the results of special research and of participating in the work of development, and in so doing of acquiring technical experience of the most advanced nature. Dr. Moritz von Rohr undoubtedly appreciated the importance of such a connexion and made the fullest use of his opportunities.

In 1913 von $R o h r$ received the additional appointment of assistant professor in the Department of Medical Optics at the University of Jena. His interests were soon diverted to the field of optics and particularly ophthalmics; but although he might have made a name for himself in the more creative field of research, he became at an early stage of his career greatly interested in the history of the science to which he had become devoted. Even in his earliest contributions the historical aspects of the subject tend to predominate over the more technical details.

Von Rohr soon became by far the most important writer in every branch of historical optics. Although his knowledge of previous writings was profound, much of his material was the result of personal research. To ensure the accuracy of the information, he travelled widely and was unsparing of his strength. Few writers on any one subject can ever have been the author of so many contributions. The list is of extraordinary length. Dr. von Rohr will be remembered not so much because of any outstanding original creative work, but rather as a historian who discovered and recorded much valuable material that otherwise would have been lost to the scientific world.

James Weir French.

\section{Prof. Hans Zinsser}

THe recent death in New York of Prof. Hans Zinsser, when he had nearly completed his sixty-second year, has removed an outstanding personality from the ranks of American bacteriologists. His work in the field of immunology and his researches during the past ten years into the prevention of typhus fever by means of a vaccine prepared from the causal organism had secured for him a world-wide reputation. Moreover, numerous interests, which extended far beyond the sphere of his scientific work, engaged his leisure hours, and thus he gave the impression of having lived intensely, even during the prolonged illness of which he clearly foresaw the inexorable end.

Zinsser was professor of bacteriology at Stanford University, California, from 1911 until 1913; at Columbia University, New York, from 1913 until 1923 ; and afterwards at Harvard Medical School, Boston. He was a member of the American Red Cross Sanitary Commission to Serbia in 1915; and in 1917 he served in the Medical Corps of the U.S. Army in France, where he acted as assistant director of the laboratories. In the summer of 1923 he visited Russia as sanitary commissioner for the Health Section of the League of Nations.
Problems investigated by Zinsser and his coworkers include : the mechanism of bacterial allergy ; the immunological significance of certain non-protein substances extracted from the tubercle bacillus and other bacterial species, a series of observations which were later illuminated by Avery and Heidelberger as a result of their pioneer work on the type-specific polysaccharides of the pneumococci; the essential identity of the various manifestations of the antibody reaction; a comparison of the precipitation and agglutination reactions as influenced by the surface, in the aggregate, of the antigenic particles exposed to the action of the antibody component; and-in a different category-studies on the causative virus of Brill's disease, of herpes and of typhus fever.

Zinsser was the author of a lucid, exceptionally well-written and deservedly popular text-book of immunology under the title "Resistance to Infectious Diseases" ; he prepared the latest edition with the aid of his colleagues Enders and Fothergill. His book "Rats, Lice and History", a popular account of the history and mode of transmission of typhus fever, won the good opinion of readers on both sides of the Atlantic not only by its solid background of knowledge but also by the numerous divagations from the main theme into the by-ways of literature and philosophy with which the reader is beguiled. $\mathrm{He}$ has also written an objective account of his life and experiences, which was recently published in the United States and has been acclaimed to be of unusual merit. We understand that the book will appear shortly in Great Britain, and we cannot doubt but that the self-portrait it contains will reveal the character of one whose interests ranged widely throughout the domains of thought and action and who, when his health finally broke down, met his fate with calm and even light-hearted courage. Perhaps, after all, it was for the best that a man of his intellectual energy should have been spared the "cruel disintegration of slow years", the tragedy of old age to which he thus alludes in the last sonnet he wrote.

G. F. Petrie.

WE regret to announce the following deaths :

Dr. William Bowie, president during 1933-36 of the International Union of Geodesy and Geophysics, on August 28, aged sixty-eight.

Prof. R. S. Dugan, professor of astronomy in Princeton University, on August 31, aged sixty-two.

Sir Henry Head, F.R.S., the eminent neurologist, former editor of Brain, on October 8, aged seventynine.

Prof. E. H. Lindley, professor of psychology in the University of Kansas during 1898-1917, on August 21, aged seventy-one.

Prof. H. H. Nicholson, professor of chemistry in the University of Nebraska during 1882-1905, on August 17, aged ninety-five.

Prof. Vito Volterra, For. Mem. R. S., formerly president of the International Committee of Weights and Measures, aged eighty. 